I Federal University of São Carlos (UFSCar), São Carlos, SP, Brazil calimajb@gmail.com

II Federal University of São Carlos (UFSCar), São Carlos, SP, Brazil aline.sociologia@gmail.com

\title{
YOUTH AND THE NEW CULTURE OF WORK: CONSIDERATIONS DRAWN FROM DIGITAL WORK
}

\section{INTRODUCTION}

In his essay, The corrosion of character: the personal consequences of work in the new capitalism, Sennett (2009) begins his discussion by talking about his meeting at an airport with Rico, the son of Enrico, whom he had interviewed 25 years earlier. The conversation takes place over the course of a flight, during which Rico goes on about his life and how mobile he is compared to his father. Based on this, the author compares the linear biography of Rico's father - a general service worker who cleans buildings, and has enjoyed successive achievements, like purchasing a house, building up savings, and talks about the role of unions in protecting jobs and the forecast for his retirement - with that of his son, characterized by social mobility: a university education, a career that started as a consultant in an investment bank, then moved to the computer industry in Silicon Valley, and then to a company in Chicago; affected by the uncertainty in the new economy, he was let go from that company and moved to New York, where he opened a small consulting firm. Rejecting his father's conformism, Rico's discourse about change and risk in his non-linear life story nevertheless reveals his own insecurity, lack of outlook and meaning in his professional career. Two generations, two different historical contexts: Fordist and post Fordist work, the new flexible capitalism.

In another story, Canadian filmmaker Denys Arcand, in his film The barbarian invasions (2003), which was the continuation of his previous work, The 
decline of the American empire (I986), about a group of university professors, I8 years later analyzes this group and now their adult children in a neoliberal context. While the professors continued their "Fordist" jobs in the public university, one of their sons worked at a financial firm in London. This son's father falls ill, a situation that sets up the confrontation between the values of a generation that benefited from the social welfare state, which is now seen as inefficient: public medical assistance, the ways of accessing alternative treatments outside the legal system. In his search for better health services, the son seeks out US private hospitals and pays for them. His values and life-style are opposed to those of his parents', through the perspective of a young, successful entrepreneur.

A third story is told by Feltran (20II) when analyzing youth involved in crime in the outskirts of São Paulo. The children of salaried workers who have worked for over 30 years in various companies, these youths disagreed with the fact that their parents earned so little after so much time working, or even worse, that after everything they had done, were unemployed. Concerned with the present, they got involved with high-risk illegal and illicit activities that provided them with access to consumer goods and a certain status in their social group. The future did not even cross their minds. Employment and a long-term career did not factor into the plans of these young people.

All three situations, although in different hemispheres, have the same message: that of economic, social, political and cultural changes since the I97os as a result of globalization and so-called flexible capitalism, when work was reset, which affected their personal lives and outlook on the future. Youth, or rather, "youths," considering their socially-defined diversity, are inserted in these changes as representing the new moment. Since the I96os, terms such as autonomy, freedom, risk, mobility, flexibility, entrepreneurship, and innovation pepper the business discourse as qualities that are expected of the workers of the future. Young people will strive to be the ideal type, the desired profile within the new culture of flexible capitalism or neoliberal logic.

In the view of Dardot and Laval (2016: I7), neoliberalism is a "rationality" that guides not only the actions of government leaders, but also the behavior of the governed, "generalized competition as a behavioral norm and the corporation as a model for subjectification." These authors show that neoliberalism not only breaks down rules, institutions, and rights, but it also produces social relationships, ways of life and subjectivities. The individual is taken to behave like a company, his precise subjectivity needs to be totally involved in the activity that he must fulfill as there is no longer any distance between him and the work he carries out. This commitment, willingness, and initiative required of the neoliberal would make up a "new" culture of work, which is represented by the instability of ties, ongoing training, flexibility and mobility between work roles and businesses, as well as the entrepreneurial character observed in work- 
ers, which is understood as the driver of innovation. These characteristics are added to the set of attributed meanings, categories, shared actions and action plans for groups that, along with their conflicts, authorizations, and breaches, organize, create, and make sense of social life and define a culture (Lima, 2010). ${ }^{\mathrm{I}}$

In this article, we analyze the incorporation of youth as an intrinsic quality of the worker in the new culture of work by using the reference of work in the information technology sector ${ }^{2}$ that in the business perspective brings together innovation and youth as synonyms of flexibility in a context of informational capitalism. Also within this sector, we prioritized "digital" workers 3 focused on creation, development, and management of software programs, applications, and digital games, as well as systems analysts, IT consultants, database administrators and others who think about productive processes in a broader perspective and create new work procedures (Lima \& Oliveira, 2017). ${ }^{4}$ Given that these workers master the logical applications for using computational languages they would, in theory, have ample autonomy in an activity that is difficult to standardize.

The discussion is based on research conducted on a population of 47 IT professionals in the State of São Paulo from 2013 to 2016. These workers were contacted using the snowball sampling technique, where one contact suggests others. Interviews were conducted in person and by Skype. Most of the interviewees were under 30 and worked in various cities in the state, at companies of different sizes, and represented a range of roles within the sector at a diversity of skill and compensation levels. Although some women were interviewed, the majority of the informants were men, which is a reflection of a characteristic of a field that bears gender stereotypes and makes working in technology a predominantly male activity. ${ }^{5}$

The article starts with a discussion about generation and youth classification followed by the business characterization of generation Y, or Millennium, an explanation of the work in information technology and what defines it, such as the constant renewal of technology, its early outdating and obsoles cence by new programming and languages, which bring about relativizing work experience through the demand for constant updating in addition to entrepreneurship and innovation, which are seen as qualities in workers. We then move onto side " $\mathrm{B}$ " of this activity in discussing the relationship between creative work and the instability of the productive process and work relations.

\section{GENERATION, YOUTH AND LABOR}

We live in times where youth has become an incontrovertible value as it represents the new, the modern, and the desirable. Being young is being open to modification, change, and risk. Young people are the ones who dictate trends. They are more informed and easily adaptable to the speed of technological innovation and its resulting time-space compression, which is emblematic of the 
"height" of capitalist modernity. We all wish we were young. The growth of mass consumption and the media contribute to this "juvenilizing" by reinforcing youth as a lifestyle that does not pertain to any particular generation, but rather to a process that has been underway since the I950s with the growing prominence of youth that peaked with the "cultural revolution" in the decade that followed.

The fact that a group of people are born at the same time does not necessarily mean that their behavior will be similar, even though they may have shared experiences or witnessed the same facts (Mannheim, I993). In other words, what is sociological cannot be deduced from what is biological. What constitutes a generation is not shared content, but rather how the content is appropriated and enables the shaping of a collective (Motta \& Weller, 2010). Just like other stages in life, youth is a social, historical, and cultural construct, which therefore has differentiated functions, representations, and meanings in each period (Bourdieu, I983; Peralva, I997; Ravasco \& Mancebo, 2010).

For example, the use of the concept of the generation disconnected from its historical-political-cultural context, the idea of a "youth," in the singular, gives importance to crystalizing and essentialist elements and draws attention to certain traits that would be common in "youth." Consequently, "youths" or "youth cultures," plural, stress "discriminatory factors that trigger internal divisions within this generational universe" and contribute to a plural and diverse view of youth (Pais, 2005: I I I). ${ }^{6}$

Diogenes's (2009) perspective on this is that youth (or youths) would represent social segments that define themselves more by their practices and ways of acting and experimenting than by set and stable concepts and references. This makes it difficult to represent youth cultures, since they are characterized precisely by their plural and mobile meanings and are not, therefore, merely a transitional stage.

Whereas institutions in a broad sense, like Government, family and school understand youth as the passage from one stage of life to another, a "transformation" for young people themselves, "their existence and action in the world is anchored in the present" (Reguillo, 2007: 52). This did not go unnoticed by the market, which is very competent at exploiting this "group," a major consumer; several product lines are aimed at this market or at the lifestyle represented by this "youth."

Nowadays, young people live in a social order marked by mobility, risk, insecurity, and uncertainty. Their biographies are traced by the process of deinstitutionalizing the course of life (Leccardi, 2005), just as Sennet (2009) discussed in Rico's path. From this point of view, we can say that the concept of youth as a transition for adult life engenders a crisis since the path of life is no longer predictable, palpable, or defined. Given the flexibility of markets and labor relations, young people are no longer certain that their formal training is a guar- 
antee for entering the labor market, or for having a career, or any stability that would enable them to plan their futures (Pais, 2005; Sennett, 2009).

Considering the increasingly fast pace at which technological innovations emerge and that computerization takes on a fundamental role in social life in general, the work of the youngest people has started to be appreciated for the fact that they can potentially be molded to the demands of productivity and, in theory, be more open to creativity and innovation, in addition to being flexible and mobile (in terms of space, time and work positions), which have become the new mantra of contemporary capitalism. Young people take on a core role in the spheres of consumption, development of digital technologies, and cultural production (Canclini, 20I2).

Not all young people, however, manage to engage in socially-valued activities marked by creativity and innovation. Most youth dedicate themselves to unstable and little valued jobs. Therefore, we can say that there are at least two youths in relation to work: a majority who are made to be insecure and excluded not just from the information-based society, but also from access to institutions and social rights, who survive on the borderline that separates the legal from the illegal and illicit, and the other group, the minority, who are inserted into the avatars of digital society and have access to rights and membership in society (Reguillo, 2010: 432).

On the one hand, there would be youth who create trends, who are better informed, connected, and integrated into the labor market, the trendsetters (Pozo, 20I2). They would also resemble the notion of "yes-yes" youth given that they appear at the center of the idealization of contemporary youth in terms of broad access to education and multiple possibilities for time-space mobility, as well as flexibility in dealing with ways of working and employment contracts. In contrast, there would be the "neither-nor" youth who neither study nor work (Cardoso, 2013), have fewer social and cultural assets and end up relegated to quite a different condition. There is no possible future for these young people, just an uninspired, immediate and often brief present (Leccredi, 2005).

The emphasis on promoting youth in society and in the contemporary work world is commonly referred to as "generation Y" in the literature on management focused on business and human resources and in the media in general. The academic debate on generation is thus replaced by the dominant notion of common sense regarding age intervals, usually from i 5 to 30 years each, which makes it possible to attribute a series of characteristics to people of the same age bracket. In this context, the increase in the population's life expectancy would lead to the coexistence of four or five different generations and at least three of them would share the same work spaces (Lancaster \& Stillman, 20 I I).

The oldest of these is the traditional, or "Belle Époque," generation, which would be made up of people born between the I920s and the mid-I940s, who are characterized by their appreciation for honor and respect, and who would 
tend to remain in the same job over a long period. This generation would be followed by the baby-boomers, who were born between the end of the Second World War and the early I96os - in the midst of the prosperity of the reconstruction of the main countries involved in the conflict and the developmental policies of the countries on the periphery - and were defined by their respect for family values, discipline in school and work, and by obedience, and reflect the height of the Fordist era. The next generation, $\mathrm{X}$, would be made up of those born between the mid-I96os and the end of the 7os, and their fundamental characteristics would be skepticism, pragmatism, and an appreciation for work (Oliveira, 2010; Loyola, 2009). Generation Y would be between generation X and that which has been called "Z." The latter would be made up of young people born since the end of the I99os, the "digital natives," who are even more intimately connected with information technology than the previous generation.

The young people who would make up generation $Y$ would be those who were born approximately between I978 and I999, and are characterized as being significantly different from the youth of previous generations. They are being prepared for jobs that have yet to be created, using technologies that have not been invented, and solving problems that are still to be defined. The young people of this generation would have the ability to deal with different technologies and learn new things, skilled at multitasking, curious and motivated by challenges. They would have acquired such attributes because they grew up in a context that severed ties with the idea of the traditional family and was in touch with many technological conveniences and virtual tools, such as paid and interactive TV, videogames, cellphones, computers, and, mainly, the internet (Loyola, 2009; Oliveira, 20 I0; Oliveira, Piccinini \& Bittencourt, 201 2; Cavazotte, Lemos \& Viana, 20I2; Lemos, 20I2). This concept of "generation Y" fits in perfectly with the business discourse when considering the productive and economic restructuring of the I 980 s and gos, the flexibility of markets and the re-establishment of work relations.

The notion of "flexibility" at work involves several dimensions. It is related not only to the ways we hire outside the traditional order of salaries, but also to the workday, the diversification of activities and roles, mastery of different types of knowledge and "creativity." Autonomy and the ways control is exerted on work tend to be decreasingly less regulated by direct surveillance and start to be more related to goals and results, which is made possible by technology and the greater responsibility of the worker.

In accepting that youth from generations $\mathrm{Y}$ and $\mathrm{Z}$ are flexible, mobile, detached, and can seamlessly deal with new technologies, motivated by challenges, among other "qualities," they would represent everything that the flexible company seeks. Consequently, spreading the idea of generations integrates and strengthens the ideological discourse of the new capitalism that aims at justifying and solidifying the insertion of youth in the unstable work market, 
in which entrepreneurship and self-responsibility of the worker point to the preferred way of entering the work world.

\section{WORK AND WORKERS IN THE INFORMATION TECHNOLOGY SECTOR}

There is no consensus regarding the definition of IT, nor is there any regarding the professional classifications and occupations that are characteristic of this sector. In discussing information technology, Castells (I999) defines this sector in a broad sense by claiming that it covers technologies in microelectronics, computation (software and hardware), telecommunications and broadcasting, optoelectronics, and even genetic engineering.

The IT sector includes a great diversity of related activities in information management (applications, production, storage, transmission, access, security), based on computer resources in search of solutions for various purposes. Having established a clear relationship to the software production "industry" (its best-known face), however, the IT sector stretches much further and has the intrinsic characteristic of permanent revolution of languages, procedures and technologies.

The profiles of the workers in the sector shows that they are very young. Data about the Brazilian Software and IT Service Industry (IBSS) show that in 2009, $5 \mathrm{I} \%$ of workers who worked in the sector were between the ages of I 8 and 29, and therefore belong to the so-called Generation Y (Softex, 20I2). This map, however, only accounts for workers with formal employment in software and IT service businesses, thus all other types of informal or flexible labor contracts are not factored into the equation. These professionals are also those who find themselves in certain occupational families according to the Brazilian Classification of Occupations (CBO) and work in companies that have IT as a main business (or an end-business). These limitations in the data show that the scope of the IT sector is much broader than the numbers show, even if these numbers are still a major indicator regarding the generational aspect.

In Brazil, the development of software companies is tied to that of hardware companies since the I970s, however the sector did not start to be more regulated and supported by the government until I984, with the first Computer Science Law (Oliveira, 2009), which grew significantly in the decade that followed because of the internet. Young people from the so-called generation $Y$ were the first to grow up in contact with computers and the internet. Thus, for many IT workers, their first contact with computers started as early as childhood, or in their early adolescence, at home, or a relative's home, or at school, and that experience could have been what led them to become interested in becoming professionals in the sector. Thiago's speech is indicative of this finding:

I have been in touch with computers ever since I was a child and I already felt that there was something in this field that I wanted. Based on that I started, like 
any child who uses computers a lot, to play a lot of games and these games brought me to the world of programming. I started making small programs for the game itself, and I really liked it (Thiago, 27, systems analyst).

Familiarity with computers is perceived as being natural in these workers' growth and learning. At first it seemed to be akin to child's play, something that was learned by doing, through experience. Over time the "play" became more serious and these young people started producing small programs, like certain online games, or seeking solutions to everyday problems through computers. This interest often led to pursuing higher education in fields like computer engineering, computer science, data processing, among others. However, this affinity since childhood is not always what leads to an education in IT, since not all professionals have formal education in the field but rather have been self-taught.

Neither formal studies nor a diploma guarantee a future given that without constant updating, the worker will not be able to remain in the field and can be easily discarded from the labor market. Consequently, since content is constantly changing, demonstrating the skill and willingness to solve problems is what makes the ideal worker; they do not necessarily have to know the answer, but must have the potential to learn, to be a "problem-solver," which is the way many of these professionals describe themselves.

Sennett (2006) develops the discussion on the topic of "uselessness" by addressing the issue of age, of "ageing." Additionally, he states that among the forces that make up the "ghost of uselessness" is the workers' fear that their knowledge and skills might not be useful or sufficient anymore and could result in losing their jobs, or worse, being excluded from access the job market. This is felt particularly in the IT field because of the speed at which new technologies, equipment and software are discovered, incorporated, and become obsolete. Although software does not "grow old" in the sense of wear and tear, given its "immaterial" nature, it does stop working with changes to hardware, i.e., with machines that do not "run" it and new software that incorporates and innovates its features and languages, adjusting itself to the specific types of businesses for which they are destined.

The new demands are not lost on IT workers who point out that the main attribute for staying in the field is the willingness to learn, to constantly update, that is, to be constantly studying:

It is a profession where you can never stop studying. [...] It is a field that changes constantly. [...] If you say "ah, I will study this here, I will learn, and I want to keep working in this field the rest of my life by just acquiring experience," then no, the technology sector is not where you should work. In the technology field, experience is very important... but if you do not have the initiative to continue learning as you acquire your experience, you will die very quickly (Eric, 37, IT consultant). 
Each project demands different skills and knowledge that differ from one to the next and if professionals are not interested in learning, then they will quickly become "obsolete." Thus, when Guido (29, risk model analyst) said that in this field you must have a "tireless profile," he summarized quite well what not getting comfortable, wanting to improve, always be innovating, being in motion, and never stop training means.

The ways of obtaining knowledge and information, staying up to date, are quite varied and go beyond the classroom. The means used for updating are made available on the internet. Workers tend to use social networks (especially groups on Facebook), blogs, forums, tutorials, YouTube channels, digital books, materials that companies make available to their employees, online courses and the news, in addition to others available on websites, like the main sources of information and updating. The training programs seem to be more perishable than in other fields and professionals note that they "age" very early, since there is this idea that keeping up with the speed of changes and the news in the field, a requirement in this career, is something for younger people.

Eric, 37, says that he "used to be young," that he is already quite mature or old for this career. In his opinion, youth is related to the never-ending ability to learn, innovate, to "think that nothing is impossible," whereas the older ones tend to resist more and are less willing to keep up with changes. In this sense, ageing has nothing to do with the physical ability to stay in the business, but rather with the "willingness" to do so, where youth have the "energy" for doing so.

Likewise, Bernardo, 28, already acknowledges differences between he and younger workers, especially as they relate to the ability to think logically:

In our field of development, we work a lot with logic and logic demands a lot of your reasoning, you must really think. Even we who are twenty-eight, thirty, we already notice a greater challenge than we did when we were young for thinking and having logical reasoning (Bernardo, 28 years, analyst developer).

Even when they claim that age is not an issue, they point out that it is necessary to have an "innovative profile," the ability to adapt to new situations and be mobile. Moreover, their family responsibilities would be smaller:

because the young person is more willing to constantly change, get to know new things. Older people already have lots of experience and are more set in their ways, want a quieter and stable lifestyle for family and all the rest; they do not want to be travelling every day and week... (Cristiano, 26, IT consultant).

In fact, it is a job for people who are updated. They can be young or old, but if they do not keep up with the latest, they fall outside the IT sector. [...] But they [the older people] are a bit more resistant to the latest trends. [...] They end up thinking that what they learned over the course of their careers is correct and that there is no way to change (Thiago, 27, systems analyst). 
The older the you are, the more you must be made to stay with the team. That is funny: the older, the grumpier people get. So, where a young person sees millions of possibilities, the older one sees millions of problems. [...] In terms of communication we also have a bit of a problem, the older person does not always speak up if there is a problem at home, whereas the younger one does, "hey, I was up playing videogames until late last night and I am wasted" (Thales, 28).

Besides reinforcing this idea that maturity, establishing a family and the accumulation of responsibilities that come with it interfere in one's ability to keep up with the latest in one's career, what Thales's brings up adds other elements. Firstly, the relationship between youth and technology. Secondly, the resistance of older people, infected with the prejudice that they keep getting "grumpier" and set up obstacles to developing business, in contrast to young people who see possibilities in problems and challenges that show up in daily work. Thirdly, Thales discusses the issue of communication, and makes it clear that the young person is more transparent, which would thus facilitate his work coordinating the team.

Paying attention to what has already been learned and avoiding the new would be characteristics of older professionals, according to the workers. Considering this, Sennett (2006: 92) says that the older workers are better "masters of themselves" and critical. They judge the training offered in training courses and thus "the experienced worker complicates the meaning of what he is learning and evaluates it according to his past."

The relationship between age and work raises the issue of experience. If aging is a problem mostly for occupations, then acquiring experience, which comes with age, would be the positive side of this process. Thus, if older people are no longer as agile and mobile as the young, then they would have work experience that the youngest have yet to acquire, which would thus represent an advantage for the former in relation to the latter. Nevertheless, considering the way the work world is currently set up, we realize that the meaning and value of experience has changed.

In the IT sector workers hold the view that experience is important, but not necessarily in the usual sense, i.e., an accumulation of technical knowledge or expertise for developing business and solving work problems; they especially identify experience as accumulated learning in terms of personal relations, instead. This is expressed in the previous discussion regarding the duration of the knowledge. If the tools, languages and techniques move all the time, embracing knowledge obtained at other times can be counterproductive. On the other hand, there is an increasing demand for skills related to communicating and interacting with others, be it with team members, superiors, or clients. Therefore, the experience being reinforced seems to be more closely related to social skills, "knowing how to speak," or "knowing how to behave," in short, "being flexible." 
I always think it is important to merge teams because those who have been in the labor market longer will share their experience and maturity with the younger people who are entering, who at times do not have much experience regarding poise at work, and that issue related to anxiety, too. [...] and even so that the most stable ones, the older people in the labor market, do not get too comfortable, either (Paula, 34).

The skills for steering interpersonal relationships forged in and by work and those for dealing with different situations are at the top of the list of qualities that professionals point to as being necessary for staying in the IT field, almost as much as the need for constant study and updating. It is in this sense that Boltanski and Chiapello (2009: 170) claim that in the new spirit of capitalism, the characteristics of workers' personalities are valued and used by the company. In other words, "communicative qualities and attention and openness to differences count more than efficiency measured by the ability to reach previously-defined objectives." The worker's flexibility, ability to adapt, and learning are worth more than the worker's technical specialties (in constant change) and experience. "Soft skills" are appreciated more than "know-how."

\section{CREATIVE WORK AS FLEXIBLE WORK}

The creative nature of work is at the core of the very concept of work as pointed out by Marx (20I I) in discussing the general intellect, i.e., the collective nature of intellectual work, the power of objective knowledge that brings about technical, scientific, and even artistic knowledge. Although it does not deepen in its characterization, the productive nature of the work of an opera singer stands out when she sells her work, which is the result of her talent, and adds value.

Nevertheless, it would not be until I99os, in the context of economic restructuring and neoliberal policies in some industrialized countries where industrial activities shift to intensive activities in knowledge of the service sector, that creative or cognitive work would become the subject of systematic research, whether it be in the theory of cognitive capitalism (Hardt \& Negri, 200I), or in the discussion of the immateriality of work (Gorz, 2005; Lazzarato \& Negri 200I), which has consequences for the debate about the ways of subordinating work to capital, or even in the possibilities for freeing the worker through controlling work more. In another aspect, the concept of creative work starts to be used in the implementation of neoliberal economic policies, classified as an economic sector - the creative economy - which covers activities marked by entrepreneurship, innovation, flexible contracts and the use of manpower. The Federation of Industries of the State of Rio de Janeiro (FIRJAN), which maps the creative industry in Brazil, shows that this sector would be made up of four major areas: consumption (publicity, architecture, design, fashion), culture (demonstrations of culture, heritage, and art, music, and performing arts), media (print, audiovisual), and technology (R\&D, biotechnology, ICT). ICT would cover the development 
of software, systems, IT consulting and robotics. This sector would represent about $2.7 \%$ of the nation's economic activity (FIRJAN, 20I6).

What these activities have in common is their "immaterial" nature, the non-tangible aspects of production and work, whose repetition and distribution would be achieved through electronic media, the internet, or books, CDs, computer programs, apps and other artifacts. Work would be restricted to concepts. Its maintenance and/or reproduction would characterize another phase that involves other service jobs or physical production for distribution (books, CDs, mobile phones, laptops, etc.). Creativity is the fundamental element for creating intellectual property; culture is understood in terms of cultural objects that are defined by the socially shared meanings they carry, and creative industries transform these meanings into economic value, where there is a convergence of arts, business, and technology (Hesmondhalgh \& Baker, 20I0; Bendassolli et al., 2009).

Within the "informational" logic, the trend would be that work become increasingly independent and creative. The information technology sector, which is paradigmatic of a new labor world, would be the one that best provides its workers the chance to exercise their creative potential and free themselves from the exploitation and routine imposed by industrial work (Cocco \& Vilarim, 2009). However, in this sector we can find workers engaged both in jobs that develop creativity and make it possible to have a heightened level of autonomy, and in activities that carry out tasks marked by standardization and routine, and there is between these two extremes a full range of situations that cannot be definitely classified as creative or not creative, autonomous and not autonomous, precarious or not precarious.

For workers, work demands creativity. Being creative is generally associated with the ability to solve problems, or to "think outside the box":

We basically work with problems. [...] You are there to think outside the box, you have to bring an innovation, a great solution. Therefore, you are always being forced to propose this solution. Moreover, the demand for this is nonstop, creativity, the ability to deal with complicated situations (Leonardo, 28).

Even though working in the sector requires creativity, the programming languages themselves limit this, since they establish standards:

In our field mathematics is very important, but mathematics provides you with a resource, so what you do with this resource is up to your creativity. Programming languages restrict creativity because they impose standards. However, there are countless languages, many ways of making them communicate with each other, and that is where creativity comes into play. [...] Creativity can be found on both levels, as much in developing the product that was conceived as an idea, as in the concept of the product (Thales, 28).

Furthermore, this sector also needs repetitive and routine, and, therefore, less creative activities: 
It is a very broad field, so it depends a lot on where you end up to be able to say whether you will develop that creativity or not. Depending on the type of job, we joke that we could be substituted by a monkey, you just click on one button like this and... I am at a place that is right in the middle: I am not limited to pressing buttons all the time, but the creativity in itself is quite difficult because your task is very specific (Laila, 25).

Creativity is therefore identified in different ways: in the need to find solutions, in the process of developing these solutions (programming itself, which languages or technologies to use, how to combine them), usability (thinking that the software or system is meant for a user and, therefore, must have an intelligible interface that is accessible and even aesthetically pleasing) and even in human relations that exist in work and in the established networks (what we call "flexibility"). The limits are also set by the work instrument, itself (the languages themselves establish standards), and by the work's controls. Moreover, since the sector is very diversified, the possibility for mobilizing creativity depends on the tasks that the worker performs on the job.

Bridi and Motim (20I4) present an example regarding routine jobs, which are represented by the work of data entry. 7 There are, however, other types of professionals in which the creative element can be relativized, such as in support roles. Cristiano, who is now a consultant, used to work in the support department of a large IT company when he did not have any specific training (before going to the university):

The position was called systems monitor. It was as if I were a support, an international call center. I had the company's mainframes and those of other companies, and I was working remotely here in Brazil as I monitored their operations. If they fell, if there were some problem, it would appear on my screen, I would call the technical supervisors, the administrators, everything was done remotely, in India, the United States, Europe (Cristiano, 26)

The activity described by Cristiano might be called high-skill telemarketing since it required knowing languages. In this case companies admit that knowing a language is the only prerequisite for the job since it is first-level support (there are other levels of support, which require more qualifications), knowledge of the product or system is basic and can be easily learned through training sessions offered by the company itself. This worker is not necessarily trained in the field, however, in many cases this work is the gateway for young graduates in the IT field who aim at making a career in major companies.

Furthermore, there is work in the so-called "software factories," which would be companies or parts of larger companies where the production process for software is guided by standardizing the activities, that is, a logic that is similar to the one that is seen in traditional industries is adopted in the production process. We cannot, however, claim that coding or programming is merely a "mechanical" activity devoid of the creative element. Some profes- 
sionals seek to draw a distinction between the work done in software factories and other programming activities that would involve greater autonomy, initiative, and creativity, what they call software boutiques; in contrast to the "factory," the "boutique," at least on the level of ideals, would involve work that is much more creative, artistic, and personalized.

Despite the rapid changes and all the uncertainties that surround the work world, in general, and the IT sector, in particular, workers still desire a stable future, at least in the long term. Regarding ways of contracting, most of the workers interviewed prefer contracts subject to the Consolidated Labor Laws, mainly because of the benefits that go with being a salaried worker and because this type of contract is financially worthwhile. This, however, goes against the grain of flexibility and mobility, which belong to a sector characterized by innovation. The unique traits of the Brazilian IT sector must also be taken into consideration, a sector in which $70 \%$ of employees have formal contracts (Softex, 20I2). This situation stands in contrast to that of countries like the United States, England, and Argentina, yet resembles other European countries whose labor relations are more regulated (Miguez \& Lima, 20I6; MayerAhujaa \& Wolf, 2007; Bergvall-Kåreborn \& Howcroft, 2013). The growing demand for these professionals in the labor market over the past I 3 years must also be considered as it placed them in the relatively comfortable situation of being able to choose the type of contract they wanted, even though salaries did not always keep up with surge in demand.

These young people were born and brought up in a world that is "liquefied" (Bauman, 200I), or rather, where short-lived relationships, the present, and the now prevail. Accordingly, it is to be expected that youth are increasingly removed from an ideal of job security and stability, a standard of life and work that marked previous generations and are more accustomed and adapted to flexible contracts. Yet, that is not what occurs. Even though they manage to see the positive aspects of flexible contracts, they seek to cling onto what (supposed) stability or security remains in formal work and do not stop making long-term plans. Although there are features in flexible contracts that are appealing when young people entering the labor market, contracts considered to be more "stable" tend to gain favor as the years go by and this group has more responsibilities.

Additionally, some workers who intend on staying in the field can envision the possibility of still working at their current company ten years from now, especially those who are at larger companies that offer career opportunities. Others who work in smaller companies and/or in smaller cities aim at finding opportunities in larger companies and/or in the state capital and even abroad, even though there are those who do not consider working and living in a big city. There are also those who plan to open their own companies once they have a good idea worth trying in the market and a certain security in that decision- 
making. However, not everyone foresees themselves in this sector until retirement. In other words, the outlook is mixed, yet the high turnover in the sector signals a permanent search for the best labor conditions possible (Softex, 20I2).

Leonardo's account highlights the importance of stability since he intends to forge a career in a solid company or open his own as soon as he figures out how to:

At first my idea is to stay in a company where I can have stability. I have thought about opening my own company, but not so much these days. Occasionally you get that idea and think "this is worth investing in," so everything depends on that gut feeling, a lot of feeling, that does not work (Leonardo, 28, IT consultant).

Others also acknowledge the obstacles in staying in the field, especially regarding the constant need to update knowledge and the intense pace of work that is required. They consider radically changing the direction of their career or even leaving the field altogether. Asked whether he intends on staying in the same job in the medium to long term, Roberto (24), who works in sales, answers that he does, but that he wants to change his way of working: "At the same company, yes, but not in the same department [...] I am working on becoming a field salesman, to hit the road. It suits my profile better." Despite wanting to stay in the sector, Felipe (28), an IT consultant, considers training even more to continue a parallel career as a university professor: "I do not want to have my own company, I aim at staying in the same one as long as I can [...] and pursuing a master's degree to be able to teach."

With this in mind, staying in the field long term is constantly a question, especially for those who have been in the labor market for a long time. In the interview with Catarina (32), she reveals that she is tormented by the thought of having to return to work the next day. She reports that she seeks to find "a way out" for her future, like opening a franchise, for example. At other times in the interview, she shows her perception that the sector is difficult by using expressions such as "the environment is very hostile," "you have to have thick skin," "people who are more sensitive suffer a lot in this field." Another interviewee, Bernardo (28), has a similar perspective:

I think that in fact, it is a kind of occupational hazard. So, I had a lot of stress, a lot of conflict, working was stressful... managers who do not see the human aspect very much. So, they just see the deadline, or they only see the resources, they treat you like a resource. [...] Abusive deadlines, extremely aggressive deadlines and with nobody to work, and you are being forced to meet it [...] being made responsible for many things that were not really mine... it is extremely irritating and off-putting (Bernardo, 28, development analyst).

Similar perceptions can be found throughout the interviews. Some negative points that Bernardo attributes to the IT sector could perhaps be extended to various fields of work. However, the discussion proves to be revealing nonetheless about freelance and creative work, in which the IT sector 
is seen as paradigmatic. Generally, professionals think that they have freedom at work since the supervision is neither constant nor on site most of the time, that is, there is no "foreman" figure who controls the worker's every move, but the control is carried out through goals or results placed on workers, that is, this worker "must regularly account for results, and the objectives assigned can be updated time and again" (Zarifian, 2002: 27).

Control is internalized by the worker and monitored by devices, which has the effect of extending the workday, inside and outside the company to the weekends and vacation; in other words, it never ends. The boundaries between work and not work are erased. Reading an e-mail, a WhatsApp message, or Messenger merges work and leisure since these could be both things at the same time (Oliveira, 2017).

A few interviewees stated that working longer than the established workday or having to work extra hours are things that occur because projects tend to be poorly sized in terms of time and resources. Consequently, if the results are not achieved by the set deadline, the worker is made responsible and, in many cases internalizes the blame and the feeling of failure, a process that causes grief.

Castro (2013) highlights that young people seem to justify and support this type of work, which has great demands in terms of speed, fulfillment, and performance. At the same time, this lifestyle brings about physical and psychological illness, which workers treat as a passing stage.

This is established in various physical and mental illnesses. The physical risks related to the pace and nature of their work include gastrointestinal problems (nervous gastritis, gastric reflux, and ulcers), headaches, migraines, change in blood pressure, eating disorders (excessive appetite and weight gain or loss), allergic reactions, low immunity, worsening of respiratory problems, tendonitis and back pain. Moreover, mental illness appears in different ways, such as depression, psychological shock, irritability, anxiety disorders, which in some cases leads to the use of painkillers, anti-anxiety medications, and others.

Eric reports a health problem in the stomach, which he relates to the "politicking" that plays a part in his workplace on a daily basis, especially in the relationship with clients and their demands. Catarina blames work for the weight she has gained for the past several years and for the difficulty she has in losing it since she is in a constant state of anxiety, which leads her to "play down" how she eats. Roberto acknowledges that he occasionally resorts to the use of painkillers or needs to "go out for a walk" to deal with workplace anxiety. Thiago says that:

I began to get a lot of gastritis and the doctor's diagnosis was that it was most likely nervous and related to stress from my job. Then I started having a lot of sentimental problems, in fact. I started to get depressed, rather irritated and it was indeed a result of my work environment (Thiago, 27). 
In addressing the types of suffering and illness caused by work, Dejours (2000:I4) points out that the economic reason, besides excluding workers who would not be suited for the job market (and, of course, they suffer), requires those who are working "to always perform better in terms of productivity, readiness, discipline and selflessness. We will only survive, they tell us, if we meet and exceed ourselves and become even more effective than our competition." These workers suffer from demands for time, pace, training, information, learning, education level and degree, experience, speed of acquiring theoretical and practical knowledge, as well as adapting to the company culture, the market demands, client relations, among others. This may explain the high mobility of these workers from job to job, even though they assimilate rationales like personal growth, greater knowledge, continuing education, flexibility and other mantras in the managerial discourse.

\section{IN CONCLUSION: A NEW CULTURE OF WORK?}

What we call a "new culture of work" (Lima, 20I0) appears in works by other authors as "culture of capitalism" (Sennett, 2006), "business culture" (Barbosa, 2002), as well as definitions of "flexible work" (Harvey, I993) and other ways of characterizing changes in work relations and conditions arising from technological and organizational changes of the era known as productive restructuring, or economic restructuring, the political term for which is neoliberalism.

This era has begun to demand a new type of worker who needs to show a series of traits, abilities, and skills to be integrated into the current flexible labor market, including being adaptable to the most diverse situations; showing ability in very diverse activities; knowing how to work in a team with very different people; being ready to develop their business in varied places with flexible workdays; being mobile; knowing how to communicate and connect through networks; having the openness necessary to deal with the new; demonstrating creativity, autonomy, and self-control; knowing how to personally manage work and "career"; being agile and reactive; working "on a project basis," thinking in the short term, being free; taking risks (Boltanski \& Chiapello, 2009; Sennett, 2009). As we can observe, these attributes go far beyond the formal and traditional aspects of being skilled, in that the subjectivity of the individual is at play and is implied in constituting this "flexible worker." The young person would have this profile, but not any young person, but rather the one who incorporated the discourse on the new temporalities of capitalism, the impermanence and permanent mobility that would be the very characteristics of the creative worker. Accordingly, we are talking about the profiles of "yes-yes" people and setting aside the excluded "neither-nor" people who neither study nor work, and whose outlook in life is remaining in unstable job markets, such as cheap hand labor in the formal-informal-illicit circuit. 
The workers we studied, the "yes-yes" type from the digital sector, are expected to be self-entrepreneurs, in a sense that is similar to informal workers whose insecurity is glamorized by the "creative" nature of their work. In the Brazilian case, they still enjoy a certain favorable market situation that is marked by regular employment, which does not mean they are stable. Their instability, however, is justified by the never-ending search for new challenges through a range of possibilities in which good compensation would be accompanied by greater production and greater pleasure in the work performed (Almeida \& Eugênio, 20I I: I4).

However, if it is rare to achieve suitability to a standard of discourse that unites pleasure and accomplishment (work-creativity-innovation), then the suitability regulates behaviors. Yet this does not mean blind adherence to the dominant business discourse. The "yes-yes" youth from the digital sector want to be flexible, yet they want stability; they want to be creative, yet they want labor conditions that make this possible.

There is a widespread perception among these workers that this field is stressful and leads to elevated levels of anxiety. This results from not only the assimilated control, but also from the pressure of deadlines that are an outcome of project-based work and the client's control on work, which complements the job of the supervisor and the technology itself, which also acts upon this control. Thus, we have the prolonged workday for handling deadlines, the blurring of the lines that separate the workplace from the space for private life through permanent access to the internet, which enables us to continue working at home, in a café, or in any other space, which reduces our free time. The tradeoff for a certain autonomy and creativity gained in the working process is the intensification of this process, which has implications on the workers' health and personal life.

The great mobility in employment and the high level of turnover for these workers could be possible sources of resistance in the absence of a collective reference for this category. The fragmentation of the sector, its diversity and the traits of the work make labor union organizing weak and unrepresentative. This does not mean that the workers are uninformed about their rights. Social networks make information available about jobs, income brackets and other data concerning the job market.

Even when working conditions are considered to be inadequate, the workers do not mention the absence of contracts governed by the Consolidated Labor Laws, or social rights. Most workers have formal contracts, but their insecurity is present daily, given the project-based work, the pressure to meet deadlines, the uncertain length of workdays, work's "colonization" of life by means of permanent work, which is not always seen as such. And finally, the perception of temporality in a new occupation, which is constantly changing as a result of the constant outdating of knowledge and skills and the fear of losing innovative energy that would mark youth. 
Youth emerges as one more quality in recruiting workers/professionals who are suited to the new times. This is not a novelty. Industrial work has long recruited young workers simply because they are more productive, have more energy and physical strength. When physical strength was replaced by machines, technical skills and attention were what marked Taylorist and Fordist mass production, but youth has continued to be an important variable for molding the worker in the new demands for productivity. In the third industrial revolution, marked by the information revolution, knowledge, subjectivity, and social skills have become important qualifications; this is clear in the media and in business organizations whose discourse features innovation - a quality inherent to generations $\mathrm{Y}$ and $\mathrm{Z}$ that highlights self- entrepreneurship and the individual pursuit for integrating into the job market. The prevailing logic is neoliberalism, according to which the collective is replaced by the individual, setting up the popular "fend for yourself" mentality. These workers, even in a favorable market situation, know that they are in a temporary situation, which is not what they want. They are top workers and have greater autonomy, yet for this they have paid a price.

Received on 3I/03/20I7 | Revised on 2I/08/20I7 | Approved on 30/08/2017

Translated by John Ellis-Guardiola

Jacob Carlos Lima is full professor of the Department of Sociology of the Federal University of São Carlos (UFSCar). He earned his Ph.D. in Sociology at the University of São Paulo (USP), and was a post-doctoral fellow at the Department of Urban Studies and Development at Massachusetts Institute of Technology (MIT). He works on research in the fields of labor sociology and economic sociology. He oversees the Laboratory for Studies on Labor, Professions and Mobility (LEST-M) at UFSCar.

Aline Suelen Pires is an adjunct professor in the Department of Sociology of the Federal University of São Carlos (UFSCar) and an associate researcher in the Laboratory for Studies on Labor, Professions and Mobility (LEST-M) at UFSCar. She earned her Ph.D. at UFSCar, and develops research in the field of sociology of labor, mainly on the topics flexible work, cooperativism and the solidarity economy, the work of information technology professionals. 


\section{NOTES}

I In Lima (2010) the concept of the culture of work is addressed by comparing expressions of capitalist culture, businesses, employment, and class, which converge to a certain extent on the incorporation of values, norms and customs that arise from the capitalist changes that started in I970s.

2 We use IT "sector" and "field" as synonyms given that that is the workers' common usage.

3 We use the terms "workers" and "professionals" interchangeably; even considering that in the field there is trend toward specific training, the matter of what constitutes a career is still fuzzy.

4 We do not use the ILO's definition of teleworking, since it is too broad when considering the work performed in different spaces using information technologies. This definition includes workers in home offices (who work from home) and call centers, whose activities tend to be highly standardized and in many cases resemble industrial work (Antunes \& Braga, 2009).

5 Research funded by FAPESP and CNPq.

6 This discussion can also be found in Guimarães (2005).

7 The work of customs data entry personnel involves inputting data into databases, access to logs in the systems, issuing information, documents, invoices, among others and is therefore monotonous and repetitive (Bridi \& Motim, 20I4).

\section{BIBLIOGRAPHY}

Almeida, Maria Isabel Mendes de \& Eugênio, Fernanda. (20I I). Autonomias táticas: criatividade, liberação e inserção profissional juvenil no Rio de Janeiro. Política \& Trabalho: Revista de Ciências Sociais, 35, p. II-28.

Antunes, Ricardo \& Braga, Ruy. (2009). Apresentação. In: Antunes, Ricardo \& Braga, Ruy (orgs.). Infoproletários: degradação real do trabalho virtual. São Paulo: Boitempo.

Barbosa, Lívia. (2002). Cultura e empresas. Rio de Janeiro: Zahar. 
Bauman, Zygmunt. (200I). Modernidade líquida. Rio de Janeiro: Zahar.

Bendassolli, Pedro F. et al. 2009). Indústrias criativas: definição, limites e possibilidades. RAE, São Paulo, 49/I, p. IO-I8.

Bergvall-Kåreborn, Birgitta \& Howcroft, Debra. The future's bright, the future's mobile: a study of Apple and Google mobile application developers. Work, Employment and Society, 27/6, p. 964-98I.

Boltanski, Luc \& Chiapello, Ève. 2009). O novo espírito do capitalismo. São Paulo: Editora WMF/Martins Fontes.

Bourdieu, Pierre. (1983). A “juventude" é apenas uma palavra. In: Questões de sociologia. Rio de Janeiro: Marco Zero, p. II2-I2I.

Bridi, Maria Aparecida \& Motim, Benilde Lenzi. (2014). Trabalho e trabalhadores na indústria de informática. Contemporânea: Revista de Sociologia da UFSCar, 4/2, p. 35I-380.

Canclini, Néstor García. (2012). Introducción. De la cultura postindustrial a las estrategías de los jovenes. In: Canclini, Néstor Garcia; Cruces, Francisco \& Pozo, Maritza Urteaga Castro. Jóvenes, culturas urbanas y redes digitales. Madrid/Barcelona: Fundación Telefónica/Editorial Ariel, p.3-24.

Cardoso, Adalberto. Juventude, trabalho e desenvolvimento: elementos para uma agenda de investigação. Caderno CRH, 26/68, p. 293-3I4.

Castells, Manuel. (1999). A sociedade em rede. Rio de Janeiro: Paz e Terra.

Castro, Barbara. (2013). Afogados em contratos: as relações de trabalho no setor de TI. Tese de Doutorado. Programa de Pós-Graduação em Ciências Sociais/Universidade Estadual de Campinas.

Cavazotte, Flávia; Lemos, Ana Heloisa \& Viana, Mila. (2012). Novas gerações no mercado de trabalho: expectativas renovadas ou antigos ideais? Cadernos EBAPE.BR, Io/I, p. I62-I80.

Cocco, Giuseppe \& Vilarim, Gilvan de Oliveira. (2009). Trabalho imaterial e produção de software no capitalismo cognitivo. Liinc em Revista, 5/2. 
Dardot, Pierre \& Laval, Christian. (2016). A nova razão do mundo: ensaio sobre a sociedade neoliberal. São Paulo: Boitempo.

Dejours, Christophe. (2000). A banalização da injustiça social. Rio de Janeiro: Ed. FGV.

Diógenes, Glória. (2009). Juventude, exclusão e a construção de políticas públicas: estratégias e táticas. In: Mendonça Filho, Manoel \& Nobre, Maria Tereza. (orgs). Política e afetividade: narrativas e trajetórias de pesquisa. Salvador/ São Cristóvão: EDUFBA/EDUFES.

Feltran, Gabriel. (20I I). Fronteiras de tensão: política e violência nas periferias de São Paulo. São Paulo: Ed. Unesp/CEM/ Cebrap.

Firjan. (2016). Mapeamento da indústria criativa no Brasil. Disponível em <www.firjan.com.br>. Acessado em 27 nov. 2016.

Gorz, André. (2005). O imaterial: conhecimento, valor e capital. São Paulo: Annablume.

Guimarães, Nadya Araujo. (2005). Trabalho: uma categoria-chave no imaginário juvenil? In: Abramo, Helena \& Branco, Pedro Paulo (orgs.). Retratos da juventude brasileira: análises de uma pesquisa nacional. São Paulo: Instituto da Cidadania/Fundação Perseu Abramo.

Hardt, Michel \& Negri, Antonio. (200I). Império: a nova ordem política da globalização. Rio de Janeiro: Record.

Harvey, David (I993). Condição pós-moderna. São Paulo: Loyola. Hesmondhalgh, David \& Baker, Sarah. (2010). 'A very complicated version of freedom': conditions and experiences of creative labour in three cultural industries. Poetics, 38 , p. 4-20.

Lancaster, Lynne \& Stillman, David. (20I I). O Y da questão. São Paulo: Saraiva.

Lazzarato, Maurizio \& Negri, Antonio. (200I). Trabalho imaterial: formas de vida e produção de subjetividade. Rio de Janeiro: DP\&A.

Leccardi, Carmen. (2005). Por um novo significado do futuro. Tempo Social, I7/2, p. 35-57.

Lemos, Ana Heloisa da Costa. Juventude, gerações e trabalho: ampliando o debate. Organização \& Sociedade, I9/63, p. 739-743. 
Lima, Jacob Carlos. (20I0). Participação, empreendedorismo e autogestão: uma nova cultura do trabalho? Sociologias, I2/25, p. I58-I98.

Lima, Jacob Carlos \& Oliveira, Daniela Ribeiro de. (2017). Trabalhadores digitais: as novas ocupações no trabalho informacional. Sociedade e Estado, 32/I, p. II5-I43.

Loyola, Rita. 2009). Geração Y. Revista Galileu, 2I9. Disponível em: <http://revistagalileu.globo.com/Revista/ Galileu/o,,EDG87165-7943-219,00 GERACAO+Y.html>. Acessado em I 2 abr. 2015.

Mannheim, Karl. (I993). El problema de las generaciones. REIS - Revista Española de Investigaciones Sociológicas, 62, p. I93-242.

Marx, Karl. (20II) [1858]. Grundisse: manuscritos econômicos de I857-I858: esboços da crítica da economia política. São Paulo/Rio de Janeiro: Boitempo/Ed. UFRJ.

Mayer-Ahujaa, Nicole \& Wolf, Harald. (2007). Working in the German Internet Industry. Critical Sociology, 33, p. 73-99.

Miguez, Pablo \& Lima, Jacob Carlos. (20I6). El trabajo cognitivo en el capitalismo contemporáneo. El surgimiento y la evolución del sector software en Argentina y Brasil. Cuadernos del Cendes, 33/96, p. 67-89.

Motta, Alda Britto da \& Weller, Wivian. (2010). A atualidade do conceito de gerações na pesquisa sociológica. Revista Sociedade e Estado, 25/2, p. I75-184.

Oliveira, Daniela Ribeiro. (2017). Do fim do trabalho ao trabalho sem fim: o trabalho e a vida dos trabalhadores digitais em home office. Tese de Doutorado. Programa de Pós-Graduação em Sociologia/Universidade Federal de São Carlos.

Oliveira, Daniela Ribeiro. (2009). Os trabalhadores da indústria de software: flexíveis e precários? Dissertação de Mestrado. Programa de Pós-Graduação em Sociologia/Universidade Federal de São Carlos.

Oliveira, Sidnei Rocha de. (2010). Geração Y: o nascimento de uma nova versão de líderes. São Paulo: Integrare.

Oliveira, Sidnei Rocha de; Piccinini, Valmiria Carolina \& Bitencourt, Betina Magalhães. (2012). Juventudes, gerações e trabalho: é possível falar em geração Y no Brasil? Organização \& Sociedade, I9/62, p. 55I-558. 
Pais, José Machado. (2005). Jovens e cidadania. Sociologia, Problemas e Práticas, 49, p. 53-70.

Peralva, Angelina. (I997). O jovem como modelo cultural. Revista Brasileira de Educação, 5/6, p. I5-24.

Pozo, Maritza Urteaga Castro. (20I2). De jóvenes contemporáneos: Trendys, empreendedores y empresarios culturales. In: Canclini, Néstor Garcia; Cruces, Francisco \& Pozo, Maritza Urteaga Castro. Jóvenes, culturas urbanas y redes digitales. Madrid/Barcelona: Fundación Telefónica/ Editorial Ariel, p. 25-44.

Ravasco, Ana Augusta M. M. \& Mancebo, Deise. (2010). Juventude, trabalho e projetos de vida: ninguém pode ficar parado. Psicologia, Ciência e Profissão, 30/2, p. 376-389.

Reguillo, Rossana. (2010). Los jóvenes en México. México: FCE/Conaculta.

Reguillo, Rossana. (2007). Las culturas juveniles: un campo de estudio; breve agenda para la discusión. In: Fávero, Osmar et al. Juventude e contemporaneidade. Brasília: Unesco/ MEC/Anped, p. 47-72.

Sennett, Richard. (2009). A corrosão do caráter. Rio de Janeiro: Record.

Sennett, Richard. (2006). A cultura do novo capitalismo. Rio de Janeiro: Record.

Softex. (20I2). Software e Serviços de TI: A indústria brasileira em perspectiva - n. 2. Campinas: Observatório Softex.

Zarifian, Philippe. (2002). Engajamento subjetivo, disciplina e controle. Novos Estudos CEBRAP, 64, 23-3I.

\section{Films}

Denys Arcand (direction and screenplay). (2003). The barbarian invasions. Distribution in Brazil: Miramax Films/Art Films

Denys Arcand (direction and screenplay). (1986). The decline of the American empire . Canada: Malofilm/Corporation Image M \& M/National Film Board of Canada/Téléfilm Canada/Société Général du Cinéma du Québec/Société Radio Cinema. Distribution in Brazil: Cineplex-Odeon Films/Art Films. 
Palavras-chave

Cultura do trabalho; juventudes; geração Y; tecnologia da informação; trabalho digital.

Keywords

Culture of work;

youth; generation Y; information technology; digital work

\section{JUVENTUDES E A NOVA CULTURA DO TRABALHO:} CONSIDERAÇÕES A PARTIR DO TRABALHO DIGITAL Resumo

$\mathrm{O}$ artigo discute de que maneira a "nova cultura do trabalho", caracterizada pelo discurso empresarial do trabalho flexível e pelas exigências de um trabalhador móvel, adaptável, criativo, inovador, autônomo e empreendedor de si, entre outros atributos subjetivos, tem no "jovem" seu tipo ideal. Assim, a "geração Y", tal como apresentada pela mídia e literatura empresarial, materializaria todas as "qualidades" desejáveis pelas empresas em relação a um trabalhador levado aos limites da flexibilidade. A partir de pesquisa realizada com profissionais da tecnologia da informação (TI) no estado de São Paulo, buscamos demonstrar que a construção de um ideal positivado de juventude criativa e inovadora obscurece o caráter intenso do trabalho com essas tecnologias, marcado pela "projetificação" e instabilidade.

\section{YOUTH AND THE NEW CULTURE OF WORK: CONSIDERATIONS DRAWN FROM DIGITAL WORK}

Abstract

This article discusses how the "new culture of work," which is characterized by the entrepreneurial discourse of flexible work and the demand that workers be mobile, adaptable, creative, innovative, autonomous and self-entrepreneurs, among other subjective attributes, holds "young people" as its ideal model. "Generation Y," as presented by business literature and media, embodies all the "qualities" that companies deem to be desirable in a worker whose flexibility is pushed to the limit. Based on research with Information Technology (IT) professionals in the state of São Paulo, we try to demonstrate that the construction of a positive ideal of creative and innovative youth obscures the intense nature of the work with these technologies, defined by "projectification" and instability. 